Mineralogy and Petrology (2007) 91: 287

DOI 10.1007/s00710-007-0215-3

Printed in The Netherlands

\title{
New evidence from a calcite-dolomite carbonatite dyke for the magmatic origin of the massive Bayan Obo ore-bearing dolomite marble, Inner Mongolia, China
}

\author{
M. J. Le Bas, Yang Xueming, Rex N. Taylor, B. Spiro, \\ J. A. Milton, Zhang Peishan
}

Published online 18 October 2007

(C) Springer-Verlag 2007

In the article "New evidence from a calcite-dolomite carbonatite dyke for the magmatic origin of the massive Bayan Obo ore-bearing dolomite marble, Inner Mongolia, China” by M. J. Le Bas, Y. Xueming, R. N. Taylor, B. Spiro, J. A. Milton, Z. Peishan [Mineralogy and Petrology (2007) 90: 223-248; DOI 10.1007/s00710-006-0177-x], the authors' names Y. Xueming, R. N. Taylor and Z. Peishan are misspelled.

They should read Yang Xueming, Rex N. Taylor and Zhang Peishan.

Verleger: Springer-Verlag GmbH, Sachsenplatz 4-6, 1201 Wien, Austria - Herausgeber: Prof. Dr. J. G. Raith, Department Angewandte Geowissenschaften und Geophysik, Lehrstuhl für Mineralogie und Petrologie, Peter-Tunner-Straße 5, 8700 Leoben, Austria - Redaktion: Peter-Tunner-Straße 5, 8700 Leoben, Austria - Hersteller: Satz und Umbruch: Thomson Press (India) Ltd., Chennai; Offsetdruck: Krips bv, Kaapweg 6, 7944 HV Meppel, The Netherlands - Verlagsort: Wien - Herstellungsort: Meppel - Printed in The Netherlands. 